\title{
Spóźniona odpowiedź? Literackie kontrnarracje o wsi i Zagładzie
}

\section{Delayed Answer? Literary Counter-Narratives of the Village and the Holocaust}

\begin{abstract}
The subject of the article are conceptualisations of the experiences of Holocaust, war and occupation (from the Polish perspective) as well as Polish-Jewish (and peasant-Jewish) relationships that were formed in the context of violence that were formulated as a part of the most recent village literature. Seemingly telling is the fact that more and more publications appearing on the Polish book market discuss the issue of the village, amongst which are works where the Holocaust happening on the „outskirts” plays a central role. Therefore the starting point for the considerations presented in the article is the question about the possible causes of the current turn towards the village being embroiled in the Holocaust. The author places this literary phenomenon in the context of current historical research concerning the so-called third wave of the Holocaust and concentrates on the analysis of two books: Sonka by Ignacy Karpowicz and A Little Annihilation by Anna Janko which seem to be particularly representative for the strategies of formulating literary responses to the findings of the historians.
\end{abstract}

Keywords: Holocaust, World War II, village, Jews, peasants, outsiders, bystanders

Streszczenie: Przedmiotem artykułu są formułowane w ramach najnowszej literatury o wsi konceptualizacje doświadczenia zagłady Żydów oraz wojny i okupacji (z perspektywy polskiej), a także relacji polsko-żydowskich (i chłopsko-żydowskich) zawiązujących się w polu przemocy. Znamienny wydaje się fakt, że w ostatnim czasie na polskim rynku czytelniczym pojawia się coraz więcej pozycji podejmujących problematykę wsi, w tym utworów, w których istotne miejsce zajmuje Zagłada dziejąca się na „obrzeżach”. Dlatego też punktem wyjścia zawartych w artykule rozważań jest pytanie o możliwe przyczyny dzisiejszego zwrotu ku wsi uwikłanej w Zagładę. Autorka sytuuje ten literacki fenomen w kontekście obecnych badań historycznych dotyczących tak zwanej trzeciej fali Holokaustu. Koncentruje się na analizie dwóch książek Sońki Ignacego Karpowicza i Matej Zagtady Anny Janko, które wydają się szczególnie reprezentatywne dla strategii formułowania literackich odpowiedzi na ustalenia historyków.

Słowa kluczowe: Zagłada, druga wojna światowa, wieś, Żydzi, chłopi, postronni, bystanders 


\author{
polskie wsie \\ mordowały żydów \\ nie zabiły jezusa \\ polskie wsie \\ przechowywały żydów \\ zabiły kalitowe dzieci \\ M. Bobula, \\ Wsie, animalia, miscellanea ${ }^{1}$
}

\title{
Zmiana topografii
}

Pojawiające się w ostatnim dwudziestoleciu publikacje na temat Zagłady $\dot{Z} y-$ dów i drugiej wojny światowej zarysowują zmianę paradygmatu w badaniach dotyczących tych doświadczeń. Określa ją z jednej strony tendencja do reorientowania i poszerzania pola badawczego o tematy pomijane lub niedostatecznie opracowane (np. problem seksualnej pracy przymusowej w obozach ${ }^{2}$ czy kategorii świadka w odniesieniu do postaw polskiego społeczeństwa wobec Zagła$\mathrm{dy}^{3}$ ), z drugiej - zwrot ku lokalności, który afirmuje badania mikrohistoryczne lub studia przypadku, podkreślając tym samym znaczenie przestrzennego ukontekstowienia aktu przemocy. Ujęcie Zagłady z perspektywy lokalnej wiąże się również z obserwowaną obecnie zmianą topografii badań. Uwaga badaczy koncentrowała się dotychczas przede wszystkim na doświadczeniu obozowym i głównych ośrodkach eksterminacji bezpośredniej - obozach zagłady i obozach koncentracyjnych - a także na etapie tak zwanej eksterminacji pośredniej, której celem było zamykanie i wyniszczanie ludności żydowskiej w gettach. Wybór tych tematów determinował preferowaną przez badaczy topografię - przebieg procesów eksterminacyjnych został bowiem lepiej opisany (i jest szerzej znany) w odniesieniu do dużych ośrodków miejskich. Publikowane w ostatnim czasie monografie naukowe świadczą tymczasem o przesunięciu uwagi z centrum na peryferie, z miasta na wieś.

Przełomowe znaczenie dla debaty nad lokalnym doświadczeniem Zagłady, ze szczególnym uwzględnieniem udziału w nim Polaków, miała oczywiście książka Sasiedzi. Historia zagtady żydowskiego miasteczka Jana Tomasza Grossa

' M. Bobula, Wsie, animalia, miscellanea, Warszawa 2018.

2 Zob. J. Ostrowska, Przemilczane. Seksualna praca przymusowa w czasie II wojny światowej, Warszawa 2018.

${ }^{3}$ Zob. Świadek. Jak się staje, czym jest?, red. A. Dauksza, K. Koprowska, Warszawa 2019. 
(2000) - wyznacza ona moment rozpoznania tematu Zagłady na polskiej prowincji ${ }^{4}$. Wspomniana publikacja zainicjowała ruch odkrywania i poznawania historii Żydów na poziomie regionalnym, co pociągnęło za sobą podejmowanie w poszczególnych miejscowościach inicjatyw upamiętniających. Pobudziła ona również wieloaspektowe i interdyscyplinarne badania nad okupacyjną historią wsi, nazwane przez Bartłomieja Krupę „nurtem chłopskim historiografii Zagłady" ". Jako jedną z pierwszych monografii podejmujących próbę refleksji nad problemem Zagłady na prowincji można wskazać publikację zbiorową Prowincja noc. Życie i zagtada Żydów w dystrykcie warszawskim, redagowaną przez Barbarę Engelking, Jacka Leociaka i Dariusza Libionkę . Publikacja ta łączy trzy aspekty, które Krupa wymienia jako charakterystyczne dla „nurtu chłopskiego historiografii Zagłady”, a mianowicie: zamierzoną interdyscyplinarność (autorzy prezentują badania historyczne, socjologiczne, psychologiczne, antropologiczne oraz z zakresu analizy dyskursu), figurę zaangażowanego autora-narratora i różnorodność tematyczną, ze szczególnym uwzględnieniem problemów dotychczas pomijanych. Warto tu też wspomnieć o pojedynczych artykułach dotyczących problemu Zagłady na prowincji, między innymi Aliny Skibińskiej i Jakuba Petelewicza Udziat Polaków w zbrodniach na Żydach na prowincji regionu świętokrzyskiego ${ }^{7}$ czy Andrzeja Żbikowskiego Krótka historia stosunków polsko-żydowskich we wsi Grądy Woniecko w roku $1942^{8}$. W wypełnianiu luki badawczej dużą rolę odegrały badania przeprowadzone w projekcie Ludność wiejska w Generalnym Gubernatorstwie wobec Zagtady i ukrywania się Żydów 1942-1945, realizowanym przez Centrum Badań nad Zagładą Żydów. Rezultatem tych badań są studia opublikowane w 2011 roku: Barbary Engelking Jest taki piękny stoneczny dzień... Losy Żydów szukających ratunku na wsi polskiej 1942-1945; Jana Grabowskiego Judenjagd. Polowanie na Żydów 1942-1945. Studium dziejów pewnego powiatu; Aliny Skibińskiej i Tadeusza Markiela „Jakie to ma znaczenie, czy zrobili

${ }^{4}$ J.T. Gross, Sasiedzi, Sejny 2000. Paweł Dobrosielski podkreśla, że publikacja ta wyznaczyła dominujący sposób mówienia o relacjach polsko-żydowskich w czasie drugiej wojny światowej. Zob. P. Dobrosielski, Spory o Grossa. Polskie problemy z pamięcia o Żydach, Warszawa 2017.

5 Zob. B. Krupa, Historia krytyczna i jej "gabinet cieni”. Historiografia polska wobec Zagtady 2003-2013, „Zagłada Żydów” 2014, nr 10, t. 2 (Materiały), s. 744-745. Znaczenie Zagłady Żydów w okupacyjnej historii wsi zajmuje niewiele miejsca w badaniach nad wsią prowadzonych przez historyków po wojnie. Okupacyjna historia polskiej wsi nie stanowiła też wtedy przedmiotu szczególnego zainteresowania etnologów, socjologów czy antropologów. Zob. Zbrodnie hitlerowskie na wsi polskiej w latach 1939-1945. Wspomnienia, pamiętniki i relacje, red. S. Durlej, J. Gmitruk, Kielce-Warszawa 2008.

${ }_{6}$ Zob. Prowincja noc. Życie i zagtada Żydów w dystrykcie warszawskim, red. B. Engelking, J. Leociak, D. Libionka, Warszawa 2007.

7 A. Skibińska, J. Petelewicz, Udziat Polaków w zbrodniach na Żydach na prowincji regionu świętokrzyskiego, „Zagłada Żydów” 2005, nr 1.

${ }^{8}$ A. Żbikowski, Krótka historia stosunków polsko-żydowskich we wsi Grądy Woniecko w roku 1942 [w:] Świat NIEpożegnany. Żydzi na dawnych ziemiach wschodnich Rzeczypospolitej $w$ XVIII-XX wieku, red. K. Jasiewicz, Warszawa-Londyn 2004, s. 744-757. 
to z chciwości?" Zagtada domu Trynczerów, a także tom zbiorowy Zarys krajobrazu. Wieśs polska wobec Zagtady 1942-1945'. W 2018 roku warszawski ośrodek badawczy wydał dwutomową publikację Dalej jest noc. Losy Żydów w wybranych powiatach okupowanej Polski, zawierającą analizy okupacyjnych losów Żydów w wybranych dziewięciu powiatach, szczególnie w okresie akcji likwidacyjnych $(1942-1943)^{10}$. Pod względem metodologicznym stanowi ona studium mikrohistoryczne, co pozwala na prześledzenie indywidualnych losów i doświadczeń, na zbadanie i zrozumienie specyfiki Zagłady z perspektywy jej ofiar.

Kontynuujące kierunek badawczy wyznaczony przez Sasiadów publikacje dotyczące Zagłady na prowincji uderzyły przede wszystkim w mit polskiej niewinności i skierowały publiczny dyskurs ku „ciemnym stronom” polskich postaw wobec Zagłady, a zwłaszcza ku problemowi (współ)udziału Polaków w mordowaniu Żydów. Kwestię miejsca polskiego społeczeństwa w Zagładzie skomplikował dodatkowo Andrzej Leder, który mianem „prześnionej rewolucji” określił procesy historyczno-polityczno-społeczne w latach 1939-1956, będące podstawą tożsamości współczesnej klasy średniej wywodzącej się w dużej mierze z warstwy chłopskiej. Wydarzenie rewolucji pozostaje jednak nieuświadomione z obawy przed przywołaniem wspomnienia dokonanej cudzymi rękami przemocy (Zagłady i likwidacji dworów), przyjęcia postawy pasywnej i zarazem transpasywnie czerpanych korzyści ze skutków tych procesów. Zapośredniczona forma udziału w Zagładzie umożliwiła - zdaniem Ledera - wyparcie polskiej odpowiedzialności i usytuowanie się w pozycji bezbronnego widza, który w istocie korzystał ze skutków działań innego podmiotu ${ }^{11}$.

Zmiana topografii w badaniach nad Zagładą (ale też tekstach kultury dotykających problematyki wsi i Zagłady) niesie z sobą zagrożenie polaryzacji pola badawczego i kolonizowania wizerunku chłopów jako homogenicznej warstwy społecznej, na co zwracał uwagę Paweł Dobrosielski w jednym z rozdziałów książki Ślady Holokaustu w imaginarium kultury polskiej ${ }^{12}$. Podkreślał on, że obecny dyskurs (także naukowy) o postawach Polaków wobec Zagłady stwarza doskonałe warunki do obarczenia chłopa winą za polskie zbrodnie na Żydach. Wieś w polskim dyskursie jest, zdaniem badacza, spychana na margines jako grupa odrębna i odizolowana od reszty polskiego społeczeństwa, co łatwo może prowadzić do konkluzji, że chłopi zajęli wobec Zagłady odmienne

9 Zarys krajobrazu. Wieśpolska wobec Zagłady Żydów 1942-1945, red. B. Engelking, J. Grabowski, Warszawa 2011; B. Engelking, Jest taki piękny stoneczny dzień... Losy Żydów szukajacych ratunku na wsi polskiej 1942-1945, Warszawa 2011. Por. J. Grabowski, Judenjagd. Polowanie na Żyów 1942-1945. Studium dziejów pewnego powiatu, Warszawa 2011; T. Markiel, A. Skibińska, „Jakie to ma znaczenie, czy zrobili to z chciwości?” Zagłada domu Trynczerów, Warszawa 2011.

${ }^{10}$ Dalej jest noc. Losy Żydów w wybranych powiatach okupowanej Polski, red. B. Engelking, J. Grabowski, t. 1 i 2, Warszawa 2018.

11 Zob. A. Leder, Prześniona rewolucja. Ćwiczenie z logiki historycznej, Warszawa 2014.

12 P. Dobrosielski, Stodota [w:] Ślady Holokaustu w imaginarium kultury polskiej, red. P. Dobrosielski, J. Kowalska-Leder, I. Kurz, M. Szpakowska, Warszawa 2017. 
stanowisko niż pozostali Polacy - to oni zatem ponoszą odpowiedzialność za „ciemne strony” wojennych relacji polsko-żydowskich. W pułapkę takiego ujęcia wpada na przykład Barbara Engelking w rozdziale poświęconym powiatowi bielskiemu ze wspomnianej książki Dalej jest noc... ${ }^{13}$, gdy dochodzi do upraszczającego, jak dowodzi w polemicznym tekście Joanna Tokarska-Bakir, wniosku o klasowej motywacji postaw wobec Żydów (za ich mordowaniem mieliby być odpowiedzialni chłopi, a za ratowanie - szlachta).

Specyficznym produktem współczesnego dyskursu zagładowego, jak diagnozuje Dobrosielski, jest egzotyzacja i zarazem demonizacja polskiego chło$\mathrm{pa}^{14}$. Tak jednoznacznie pejoratywny wizerunek wsi okazuje się jednak problematyczny w kontekście rozpoznania oraz uznania chłopskiego pochodzenia większości polskiego społeczeństwa. Wypowiedzenie dziś tożsamościowej deklaracji „jestem ze wsi” już nie szokuje ani nie jest powodem do wstydu, wręcz przeciwnie - stanowi nobilitację wiejskiego pochodzenia. Rehabilitowane i na nowo odkrywane chłopskie dziedzictwo rodzi pokusę afirmowania jego pozytywnych elementów i wzorców; tego, co świadczy o jego wartości i ugruntowuje jego znaczenie jako wcale nie gorszej alternatywy dla ideału szlacheckich korzeni. Dlatego też proces odpominania historii ludowej Polski i przepracowywania doświadczenia pańszczyzny - co, rzecz jasna, jest absolutnie konieczne do pełniejszego zrozumienia polskiej historii i kultury - rozpoczął się od powrotu Jakuba Szeli. Sygnalizują go zarówno teksty kultury (na przykład spektakl W imię Jakuba S. Pawła Demirskiego i Moniki Strzępki z 2011 roku czy powieść Báśn o wężowym sercu albo wtóre stowo o Jakóbie Szeli Radka Raka z 2019 roku), jak i badawczy namysł nad historią chłopskich buntów ${ }^{15}$. Przywołanie tradycji buntu jako elementu (re)konstruowanego chłopskiego dziedzictwa pozwala zrewidować stereotyp bierności i bezwolności chłopskiej oraz kreować mocny podmiot, który jest zdolny do stawiania oporu i do gniewu jako sposobu wyrażania własnej podmiotowości. Z takim ujęciem trudne do pogodzenia są portrety chłopów sprawców i postronnych, jakie w polskim imaginarium Zagłady zakodował Paweł Łoziński za sprawą swojego filmu Miejsce urodzenia (1992). O silnym oddziaływaniu tego obrazu świadczyć mogą aluzje (świadome bądź nie) do poszczególnych scen lub podobne ujęcia pojawiające się w późniejszych dziełach filmowych, takich jak Poktosie Władysława Pasikowskiego czy Ida Pawła Pawlikowskiego, które potęgują negatywny wizerunek chłopa. Zarysowujący się więc paradoks we współczesnym obrazie wsi prowadzi - jak ujmował to we wspomnianym już artykule Dobrosielski - do

13 Zob. J. Tokarska-Bakir, Btad pomiaru. O artykule Barbary Engelking „Powiat bielski”, „Teksty Drugie” 2018, nr 5.

${ }_{14}^{14}$ P. Dobrosielski, Stodota..., dz. cyt., s. 378.

15 Zob. np. D. Jarosz, G. Miernik, „Zhańbiona” wieś Okót. Opowieści o buncie, WarszawaKielce 2016; M. Rauszer, Bękarty pańszczyzny. Historia buntów chtopskich, Warszawa 2020; A. Leszczyński, Ludowa historia Polski, Warszawa 2020. 
„rozszczepienia figury chłopa” na tego, który z jednej strony ma „pramordę i zabijał Żydów (z nim nie mamy nic wspólnego)”, a z drugiej jest „ucieleśnieniem naszego dziedzictwa (praprzodek w pięknym stroju, ciekawe obyczaje i smaczna swojska kuchnia)"16. To podwójne oblicze chłopskości, o którym pisze (ironizując) Dobrosielski, nie stanowi jedynie naiwnej kreacji samopotwierdzającej, ale wiąże się z trudnym do rozmontowania tożsamościowym, pamięciowym i kulturowym klinczem. Warto zwrócić się w tym miejscu do najnowszej literatury przedstawiającej wieś i sprawdzić, czy i w jaki sposób reaguje ona na „rozszczepienie figury chłopa”, jakie miejsce w (re)konstruowanym dziedzictwie chłopskości przyznaje Zagładzie i za pomocą jakich strategii buduje nową (?) narrację o wsi.

\section{Spóźniona odpowiedź}

Przywołana pokrótce trajektoria badań historycznych nad tak zwaną trzecią falą Holokaustu wydaje się budować istotny kontekst dla najnowszej literatury przedstawiającej wieś, zwłaszcza dla utworów podejmujących problematykę uwikłania polskiej wsi w Zagładę, takich jak Ludzka rzecz Pawła Potoroczyna (2013), Sońka Ignacego Karpowicza (2014), Mata Zagtada Anny Janko (2015), Skoruń Macieja Płazy (2015), Rdza Jakuba Małeckiego (2017) czy ostatnia książka Wiesława Myśliwskiego Ucho igielne (2018). Powrót do tematu wiejskiego w literaturze przełomu XX i XXI wieku - jak przekonuje Przemysław Czapliński - trudno traktować jako kontynuację „nurtu chłopskiego” wyodrębnionego przez Henryka Berezę. Czapliński zaznacza, że współczesna literatura nawiązuje do tego dziedzictwa, ale nie występuje w roli dziedzica; jest „pozbawiona wyrazistych celów, lokuje się w polskim życiu literackim jako mediator między dyskursami zarządzającymi wizerunkiem wsi i decydującymi o jej losie” ${ }^{17}$. Podczas gdy w literaturze „nurtu chłopskiego” temat zagłady Żydów pojawia się przeważnie na jej marginesach, w postaci niejasnych powidoków, fragmentarycznych i szczątkowych obrazów (szczególnym przypadkiem jest tu twórczość Leopolda Buczkowskiego ${ }^{18}$, Tadeusza Nowaka ${ }^{19}$ lub Wiesława Myśliwskiego ${ }^{20}$ ), to nowa literatura o wsi obiera za punkt odniesie-

16 P. Dobrosielski, Stodota ..., dz. cyt., s. 379-382.

17 P. Czapliński, Śmierć, śmierć, inne życie. Wieś w literaturze polskiej przetomu XX i XXI wieku, „Teksty Drugie” 2017, nr 6, s. 13.

${ }_{18}$ Zob. K. Koprowska, Klucz do domu, którego nie ma. „Czarny potok” Leopolda Buczkowskiego jako studium oikocydu, ,Teksty Drugie” 2020, nr 3, s. 283-302.

19 Zob. A. Jarzyna, Imaginauci. Pismo wyobraźni w poezji Bolestawa Leśmiana, Józefa Czechowicza, Krzysztofa Kamila Baczyńskiego, Tadeusza Nowaka, Łódź-Kraków 2017.

${ }^{20}$ Zob. B. Krupa, II wojna światowa w prozie Wiestawa Myśliwskiego [w:] Myśl Myśliwskiego (studia i eseje), red. J. Olejniczak, M. Boniecka, P. Zając, Katowice 2018. 
nia (często niejawnie) najnowsze ustalenia historyków dotyczące doświadczenia Zagłady i wojny dziejącej się w wiejskiej topografii. Jest ona w dużej mierze rezultatem przemyślenia lub choćby zapoznania się z badaniami prowadzonymi z perspektywy „po Jedwabnem”, które rewidują problem relacji polsko-żydowskich podczas okupacji, postaw Polaków wobec Zagłady, a zwłaszcza ich aktywnego udziału w mordowaniu Żydów jako sprawców oraz znalezienia się w kłopotliwej pozycji bystandera (świadka/postronnego).

Proza ta stanowiłaby więc rodzaj spóźnionej reakcji, odpowiedzi poniewczasie bądź odrabianej lekcji, którą literaturze współczesnej zadali historycy. Ze względu na tak ujęty moment jej powstawania koresponduje ona również $\mathrm{z}$ „narracjami pojedwabieńskimi”, powstającymi w odpowiedzi na publikację Sasiadów. Marta Tomczok posługuje się tą genologiczną klasyfikacją w odniesieniu do opowieści popkulturowych, które ujawniają charakter naprawczy. Oferują polskiemu społeczeństwu różne scenariusze nie tylko oswajania zbiorowej winy, ale także jej negocjowania (niekiedy za cenę niezgodności z historią). Ich stawką - co wydaje mi się szczególnie istotne - jest pytanie o tożsamość i poszukiwanie sposobów kształtowania jej na nowo (które oczywiście przyjmuje różne, czasami zupełnie odmienne, kierunki i formy) ${ }^{21}$. W nowej literaturze o wsi pisarze nie pytają już o wieś przemieszczoną do miasta (nie interesuje ich zatem to, co stało się dla Berezy głównym wyróżnikiem identyfikującym chłopskich pisarzy), lecz zastanawiają się nad specyfiką (po)chłopskiej tożsamości oraz złożoną i różnorodną przeszłością współczesnej wsi, której elementem jest też uwikłanie w doświadczenie Zagłady. W jednym ze swoich esejów Joanna Tokarska-Bakir przenikliwie diagnozowała wizerunkowy problem polskiej wsi:

Jeśli nie po pierwszej, to z pewnością po drugiej wojnie światowej polska wieś ostatecznie straciła swój sielski charakter. Na poziomie faktów historycznych wiązało się to z zanikiem dworu i Żydów, dwóch istotnych czynników (...) silnie skorelowanych z niezakłóconym trwaniem tożsamości środkowoeuropejskiej. Na poziomie świadomości łączyło się to natomiast z niewspółmiernymi, co prawda, ale dalekosiężnymi etycznymi implikacjami obu tych „zniknięc’”22.

Nowa literatura o wsi - zwłaszcza ta, która powraca do doświadczenia Zagłady i wojny - pojawia się więc w momencie, gdy dotychczasowe narracje o wsi zostały już przez historyków zdekonstruowane, a ich zasadność podważona. Tworzona dziś proza o wsi staje więc przed zadaniem sformułowania nowych narracji i nowego języka do opowiedzenia na nowo o okupacyjnej historii polskiej wsi z uwzględnieniem jej ciemnych kart.

${ }^{21}$ Zob. M. Tomczok, Czyja dzisiaj jest Zagtada? Retoryka - ideologia - popkultura, Warszawa 2017, s. 268.

${ }^{22}$ J. Tokarska-Bakir, Rzeczy mgliste. Eseje i studia, Sejny 2004, s. 73. 


\section{Kontrnarracyjność}

Literatura powstała w ostatnim dwudziestoleciu przedstawia okupacyjne losy wsi z perspektywy przeciwhistorii; za swój punkt odniesienia obiera ona konkretną narrację dominującą o doświadczeniu drugiej wojny światowej, z którą wchodzi w dialog, polemizuje i pertraktuje; którą próbuje podważyć i naruszyć przez konfrontację z tym, co peryferyjne oraz nienormatywne. Sprzeciwia się ponadto ujednoznacznionemu obrazowi wsi - albo sielskiej, albo strasznej - i próbuje (z różnym skutkiem) wyjść poza paradygmat jednostronnego mówienia o chłopskim doświadczeniu, w którym splatają się okupacyjne trudności i represje ze świadkowaniem prześladowaniom Żydów i udziałem chłopów w Zagładzie. Nowa literatura o wsi wskazuje więc na problem, którego do tej pory nie udało się rozwiązać historykom - a mianowicie złożoności i relacyjności pola przemocy, a także labilności granic między ofiarami, świadkami, postronnymi i sprawcami, wzajemnych splotów, powiązań i zależności między różnymi aktantami uwikłanymi w doświadczenie zbiorowej przemocy. Przyglądając się z tego punktu widzenia najnowszej literaturze, można wyróżnić dwa główne przeciwnarracyjne gesty organizujące różne poziomy narracyjno-fabularne utworów o wsi.

Pierwszy z nich, przyjmujący postać literackiej transgresji, konceptualizuje okupacyjne doświadczenia wsi jako przykład „historii niekonwencjonalnej”, jako opowieść o doświadczeniu cywilnym, które nie mieści się w ramach tradycyjnej, polskiej historiografii, a szczególnie dominującego w niej - bohatersko-martyrologicznego - ujęcia ${ }^{23}$. Przekraczająca je proza proponuje nieheroiczne opowieści, które afirmują los „ludzi nieznacznych”24 oraz wydarzenia dziejące się na poziomie lokalnym i w obrębie małych społeczności. W Skoruniu Macieja Płazy wzmianka o wojnie zostaje skwitowana stwierdzeniem „bohaterów u nas nie było”, we wsi pojawili się natomiast „niby-partyzanci”, którzy pod koniec wojny zaczęli rabunkową działalność i na swoim koncie mają śmierć Żydów ${ }^{25}$. Gest przeciw-narracji wydaje się również kluczowy dla powieści Sońka Ignacego Karpowicza $^{26}$, w której kreacja tytułowej bohaterki zostaje nakierowana na dekonstruowanie zmitologizowanego wyobrażenia wsi jako przestrzeni swojskości

${ }^{23}$ Wśród prowadzonych w ostatnim czasie badań nad drugą wojną światową Sławomir Buryła wyróżnia prace historiograficzne dotyczące kampanii wrześniowej, martyrologii i zagłady Kresów, dziejów konspiracji i państwa podziemnego, a także wybuchu i przebiegu powstania warszawskiego. Zob. S. Buryła, Literatury wojny i okupacji. Koncepcja stownika, „Teksty Drugie" 2020, nr 3, s. 24.

24 A. Dauksza, Ludzie nieznaczni doświadczaja przemocy II wojny. O potrzebie badania świadectw bezsilności, „Teksty Drugie” 2020, nr 3.

25 M. Płaza, Skoruń, Warszawa 2015, s. 50.

26 I. Karpowicz, Sońka, Kraków 2014. Fragmenty powieści cytuję za tym wydaniem, dalej stosując skrót S i podając w nawiasie numer strony. Powieść Sońka analizowałam wcześniej 
i sielskości. Historię Sońki naznacza wielokrotne wykluczenie: jest kobietą, która urodziła się i mieszka na wsi położonej na pograniczu polsko-białoruskim, nie potrafi pisać i posługuje się miejscowym językiem, jest wyznania prawosławnego; jednocześnie zajmuje osobne miejsce w wiejskiej wspólnocie jako szeptucha oraz ta, która przez romans z obcym i wrogiem (esesmanem) złamała wspólnotowe i moralne zasady. Karpowicz tworzy więc modelową przeciw-bohaterkę, którą identyfikuje to, co marginalne, niejednoznaczne i mniejszościowe; która odpowiada też na luki w obrębie samego nurtu wiejskiego (zwłaszcza na nieobecność opowieści babskich).

Spojrzenie na wieś przez pryzmat kobiecego losu ujawnia opresyjność wiejskiej wspólnoty, wynikającą z umocowania jej w systemie patriarchalnym, a także przemoc wpisaną w ten porządek społeczny. Dla bohaterki powieści Karpowicza wieś staje się bolesnym ciężarem traumatycznych doświadczeń, związanych z funkcjonowaniem w ustrukturyzowanej społeczności, która rządzi się ściśle określonymi (choć niepisanymi) regułami naoczności (i słyszalności), sąsiedzkiej bliskości czy braku anonimowości: „Wieś to mały świat, w zasięgu słuchu i wzroku, wszyscy żyją tak blisko siebie, że nic niczyjej uwagi ujść nie może, a potem - kara, rzadko sprawiedliwa" (S, s. 54). Prawo do prywatności i jednostkowej tożsamości jest Sońce co rusz odbierane - najpierw w przestrzeni domowej przez ojca, któremu córka zastępuje kochankę, potem w przestrzeni publicznej, gdy zostaje brutalnie ukarana gwałtem za romans z esesmanem Joachimem.

W transgresyjnym/nieheroicznym ujęciu wsi doświadczenie Zagłady pojawia się z perspektywy polskiej, w kontekście relacji polsko-żydowskich, a konkretniej - postawy Polaków wobec Zagłady. Najnowsza literatura o wsi w centrum polskiego doświadczenia sytuuje przede wszystkim problem świadkowania Zagładzie z pozycji „podmiotu uwikłanego” (Michael Rothberg) - tego, który nie podejmuje zasadniczo żadnych działań (nie zabija, nie denuncjuje ani nie ratuje), lecz w szczególny sposób asystuje Zagładzie swoją bierną obecnością; staje się częścią aktu przemocy, przyjmując rolę „bystandera” - „stojącego przy”, stacza, obserwatora czy gapia. Trudna do skonceptualizowania postawa postronnego powraca we wspomnianej powieści Karpowicza - ale też w Uchu igielnym Myśliwskiego - w widoku „znikania” Żydów: zgromadzenia ich na rynku przed rozstrzelaniem (u Karpowicza) lub prowadzenia ich z getta na dworzec, tuż przed wywózką (u Myśliwskiego). W Sońce moment rozpoznania bycia uwikłanym/uwikłaną w śmierć Żydów zostaje opowiedziany dwojako - najpierw w trybie baśniowej niesamowitości, a następnie w intymnym zwierzeniu. Ryszard Koziołek w eseju Esesman, mój bliźni podkreśla, że Karpowicz zgrabnie unika w ten sposób „banalnego lamentowania nad niewyrażalnością traumy wojennej. (...) Nieadekwatność, niezrozumienie, rozminięcie się słów i rzeczy dociera

z perspektywy konceptualizacji miejsca urodzenia: K. Koprowska, Konflikt miejsca urodzenia w „Sońce” Ignacego Karpowicza, „Tematy i Konteksty” 2017, nr 7, s. 345-358. 
do czytelnika bez negatywnych przedrostków, za to z przejmującą trafnością" ${ }^{27}$. W akt identyfikowania Zagłady Karpowicz angażuje również czytelnika, którego zadaniem jest odczytanie wplecionych w narrację sygnałów i powidoków z przeszłości nadających elementom codzienności niesamowity charakter: „tłuste krasnale stały rzędem w ogrodzie jak w obozie koncentracyjnym”; „golf, made in Germany, jak koszmar, który Sonia przeżyła”. Projekt rozpoznawania Zagłady, zaplanowany przez Karpowicza dla czytelnika, opiera się na gradacji i stopniowaniu przeżyć - pojawiające się początkowo znaki odsyłają do obiegowych i ogólnych wyobrażeń z tekstowego i wizualnego kanonu Zagłady, stopniowo perspektywa się zawęża, przybliżając czytelnika do historii zagłady Żydów z jednej miejscowości, kontekstu lokalnego, prywatnego, wreszcie - do jednostkowego losu.

Wojna i Zagłada przenika subwersywnie do baśniowej narracji o miłości Soni i Joachima poprzez przeczucia i domysły wyrażone w Zagładowych kliszach, które nabierają złowrogich sensów ${ }^{28}$. Joachim tak projektuje przyszłe życie z Sonią:

Już niedługo wojna się skończy. (...) Potem weźmiemy ślub. Będziesz czasem gotować polnische jedzenie. Wszystkim posmakuje. Będziemy mieli pięcioro dzieci: Waschil, Griken, Jan, Phrosch, Schiessen. Będziemy jeździć do kurortów i nad morze (morze to po niemiecku Juden). Będziemy mieli kota o imieniu Raus. Kot będzie się wygrzewać w słońcu i łowić Schweine (to po niemiecku myszy) (S, s. 56).

Sonia w puste powłoki niemieckich słów, wypowiadanych przez Joachima, wkłada własne wyobrażenie i pragnienie szczęśliwego życia z ukochanym. Zagłada miejscowych Żydów zostaje tym samym wmontowana w scenariusz romantycznej miłości zakończonej happy endem. Poetyka baśniowości, która przysłania moment rozpoznania cudzego cierpienia i śmierci i jednocześnie oddala go od podmiotu konfrontującego się z makabrą, wydaje się rodzajem reakcji na to, co nieoswojone - to, co jest zrozumiałe afektywnie i cieleśnie, ale co nie poddaje się upojęciowieniu i racjonalizacji. Kamuflaż staje się więc zarówno formą magicznego zaklinania rzeczywistości, jak i pośredniego wyrażenia trudnych afektów. Sońka przyznaje: „za dużo rozumiem w tym kompletnym niezrozumieniu" (S, s. 57) - wydaje się zatem świadoma niemożliwej do pogodzenia podwójności swojego doświadczenia, trwania między wiedzą (o Zagładzie miasteczka, o tym, co robi Joachim) a namiętnością i miłością, czy wreszcie między pozorem, kamuflażem i baśniowością a konfrontacją z Realnym.

27 R. Koziołek, Dobrze się myśli literatura, Wołowiec 2016, s. 183.

${ }^{28} \mathrm{O}$ nawiązaniach do Zagłady w Sońce pisze też Barbara Sienkiewicz, zob. taż, Ślady wojny i Holokaustu w sieci spotecznych dyskursów. O „Ościach” i „Sońce” Ignacego Karpowicza [w:] Ślady II wojny światowej i Zagtady w najnowszej literaturze polskiej, red. B. Sienkiewicz, S. Karolak, Poznań 2016. 
Przełomowy moment, w którym opada zasłona baśniowości i następuje pełne rozpoznanie doświadczenia Zagłady, ostateczna konfrontacja z zapamiętanym widokiem „znikających” Żydów, umożliwia spotkanie z przybyszem spoza wiejskiej wspólnoty - Igorem Grycowskim, młodym reżyserem. Sońka traktuje Igora jako ostatniego powiernika swojej opowieści, uczestnika rozmowy-spowiedzi, podczas której może wypowiedzieć swoje doświadczenia, przekazać je i tym samym wyzwolić się od ich ciężaru. Dlatego też druga opowieść Soni o zagładzie gródeckich Żydów zostaje już pozbawiona pozoru baśniowości:

Byli to ludzie starzy, pachnący kurzem i naftą z lamp; byli tam młodzi, pachnący słońcem i świeżym potem. Za kordonem żołnierzy gromadzili się mieszkańcy Gródka. Niektórzy współczuli, niektórzy nie rozumieli, niektórzy liczyli na umorzenie długu. Niektórych bawiło nagłe upokorzenie majętniejszych sąsiadów, niektórych przerażało. (...) Podobno nikt nic nie mówił. Niemcy pojedynczo wyciągali ludzi, przystawiali broń do skroni i pociągali za spust. Każdy taki upadek wyrywał kilka osób z kręgu obserwujących zajście sąsiadów. Ci ludzie szli do domów, jednak nie własnych. Widząc śmierć sklepikarza, udawali się do opuszczonego sklepu. (...) Niemcy po prostu odeszli, jakby to zdarzenie nie miało większego znaczenia, jakby skończył się czas pracy i przyszła pora na odpoczynek. Niemal setka martwych, troje żywych i muchy. Taka była, być może, historia Joachima. Już nie myślałam, że Juden to po niemiecku morze, że Raus to kot, a Schweine to myszy (S, s. 59-61).

Sonia przechowuje trudną do zniesienia i zrozumienia prawdę nie tylko o swojej biernej postawie wobec śmierci innych, ale także o reakcjach mieszkańców zgromadzonych wokół miejsca egzekucji. Okazuje się więc, że zostaje ona włączona we „wspólnotę gapiów Zagłady”, zakładników pamięci, powiązanych ze sobą nakazem zbiorowego milczenia. Przywołanie przez Sońkę zamordowanych Żydów zmienia trajektorię dalszej opowieści, która znacznie się brutalizuje; znika nadzieja na szczęśliwe zakończenie baśni, a wraz ze śmiercią syna, męża i kochanka świat bohaterki ostatecznie się rozpada.

\section{Zagłada jako niechciane dziedzictwo}

Swoją książkę o pamięci wielokierunkowej Michael Rothberg rozpoczyna od przywołania modelu pamięci rywalizującej, za pomocą którego ujmuje zderzenie dziedzictwa niewolnictwa i kolonializmu z pamięcią o nazistowskim ludobójstwie w Stanach Zjednoczonych. U podstaw tej konfrontacji Rothberg identyfikuje kluczowe pytanie o relację i związki między historiami wiktymizacji 
różnych grup społecznych w obrębie podzielanej pamięci zbiorowej ${ }^{29}$. Do rozważenia podobnego pytania skłania książka Mata Zagtada Anny Janko ${ }^{30}$, która prezentuje inny niż Sońka gest tworzenia przeciwnarracji o wojennej historii wsi, ujawniający charakter agonistyczny i eksponujący współzawodnictwo pamięci.

Książka Janko, która ze względu na wymiar autobiograficzny jest oczywiście innym typem pisarstwa niż powieść Karpowicza, stanowi rodzaj resentymentowo-afektywnej interwencji w pole pamięci, dziedzictwa i dyskursu o drugiej wojnie. Autorka gdzie indziej też identyfikuje dominującą narrację, wobec której formułuje opowieść o pacyfikacji w 1943 roku wsi Sochy na Zamojszczyźnie. Jej pisarska strategia polega na ukazaniu okupacji na wsi jako tematu pomijanego i znajdującego się na obrzeżach badań na temat drugiej wojny światowej, zdominowanych przez doświadczenie zagłady Żydów, a także na podjęciu polemiki z przechwyceniem wizerunku chłopa jako winnego/sprawcy i upominającą się o odpominanie losu chłopów jako ofiar. Dobrze istotę rzeczy rozpoznaje w swojej recenzji MartaTomczok, zdaniem której prowokacyjne postawienie sprawy i jej dość chaotyczne, bezładne rekonstruowanie wydaje się zamierzonym retorycznym rewanżem.

Szaleńczy dyskurs "małej zagłady” - pisze Tomczok - to w istocie konkurencyjna wypowiedź o tym, co piszący na temat „Wielkiej Zagłady” pomijają, o martyrologii mieszkańców wsi polskich, których po publikacji Grossa uczyniono prawie wyłącznie sąsiadami-zbrodniarzami. Jedwabne odebrało Polakom godność ofiar wojny. Książka Janko im tę godność zwraca ${ }^{31}$.

Stawka współzawodnictwa pamięci jest niebagatelna - dotyczy ona bowiem kwestii tożsamości, godności i uznania w polu symbolicznym okupacyjnej historii wsi.

Pokazane w książce Janko doświadczenie zagłady Żydów funkcjonuje niejako na dwóch poziomach - dyskursywnym i lokalnym. Jako dyskursywny punkt odniesienia Zagłada ogranicza się przede wszystkim do wątku eksterminacji bezpośredniej i historii obozowej. W tym też kontekście jest ona konceptualizowana jako niemieckie dziedzictwo narodowe, a niechciany polski spadek:

Moim zdaniem najlepiej by było, żeby Niemcy zabrali do siebie te wszystkie swoje obozy, które zostały po nich w Polsce. Żeby się już więcej nikomu nie myliło. Żeby Amerykanie nie mówili „polskie obozy śmierci”, bo ja wtedy czuję wściekłość tak silną, że sama mogłabym te baraki przenosić. A co to za problem w dzisiejszych

29 Zob. M. Rothberg, Pamięć wielokierunkowa. Pamiętanie Zagtady w epoce dekolonizacji, tłum. K. Bojarska, Warszawa 2015, s. 14.

30 A. Janko, Mata Zagłada, Kraków 2015. Fragmenty powieści cytuję za tym wydaniem, dalej stosując skrót MZ i podając w nawiasie numer strony.

${ }^{31}$ M. Tomczok, „Ptacz genów”, „Narracje o Zagładzie” 2015, nr 1, s. 326. 
czasach, skoro się klasztory i pałace przenosi na inne kontynenty (...). I jeszcze żeby jakimś cudem te miliony duchów pomordowanych ludzi, których z wszystkich krajów Europy Niemcy nam tu zwieźli, też się zabrały na Zachód. Lżej by się tutaj oddychało... (MZ, s. 107).

Otrzymanie niechcianego i cudzego dziedzictwa - jak sugeruje przywołany fragment - wywołuje emocjonalno-afektywną reakcję opartą na sprzecznościach i dysonansach. Gniew i wściekłość łączą się w niej z bezsilnością, żalem i pretensją. Ta buzująca mieszanka afektywna stanowi doskonałą podbudowę dla resentymentowego postrzegania historii i pamięciowego współzawodnictwa ${ }^{32}$.

Doświadczenie żydowskie zostaje także ujęte w kontekście lokalnym. Przyjmuje ono postać fragmentaryczną, zostaje bowiem ulepione ze strzępów wspomnień, wrażeń, poruszonych obrazów, zapamiętanych przez matkę autorki Teresę Ferenc i zarazem główną bohaterkę tej opowieści. W odniesieniu do losu Żydów z okolicy zostają zatem przywołane trzy zdarzenia, które znalazły się w zasięgu percepcji małej dziewczynki: ucieczka żydowskiego chłopca przed goniącymi go Niemcami, który po drodze zrywał z krzaków trujące owoce i je zjadał; spadające kawałki świętych ksiąg z podpalonej przez Niemców synagogi w Zwierzyńcu, które w nieco baśniowej poetyce zostają porównane z płatkami śniegu i ukazane jako niezwykłe zjawisko; Żydzi zgromadzeni na placu w miasteczku. Przywołam fragment rekonstruujący to trzecie wspomnienie:

Kiedyś, nie pamiętasz, czy zaraz potem, a może nawet przedtem, byłaś ze swoją mamą w Zwierzyńcu i widziałaś tych Żydów, których księgi spłonęły. Siedzieli na placu, smutni bardzo, z tobołkami, z dziećmi, które płakały. Patrzyłaś na nich i potem w twojej głowie obraz spadających płatków spalonych ksiąg nałożył się na ten widok. I odtąd masz ich na ekranie pamięci siedzących na placu, obsypywanych popiołem, który leci z nieba, jak w zadymce znikających, coraz bardziej szarych. „Nie patrz tak na nich, nie patrz - powtarzała twoja mama, kiedy szłyście koło nich tamtędy - bo im jest bardzo przykro...” (MZ, s. 91).

Postawa postronnego uwikłania w Zagładę zyskuje tu wizualną identyfikację ${ }^{33}$; łączy postawę patrzącego i widza. Bohaterka widzi więc żydowskich mieszkańców czekających na śmierć; przeczuwa ich koniec, choć może nie w pełni sobie go uświadamia. Jej afektywną reakcję na cudze cierpienie suponuje wyobrażeniowo-pamięciowe zestawienie dwóch obrazów siedzących Żydów i spalonych

32 Symboliczną realizację wyrażonego w tym fragmencie życzenia autorki można skądinąd dostrzec w projekcie artystycznym Łukasza Surowca, w ramach którego artysta przesadzał drzewa z Birkenau do Berlina pod hasłem przywrócenia Niemcom ich „dziedzictwa narodowego”. Zob. J. Małczyński, Krajobrazy Zagtady w sztuce wspótczesnej [w:] tegoż, Krajobrazy Zagtady. Perspektywa historii środowiskowej, Warszawa 2018, s. 195-207.

${ }_{33} \mathrm{O}$ postronnym jako podmiocie wizualnym zob. R. Sendyka, Od obserwatorów do gapiów. Kategoria bystanders i analiza wizualna, „Teksty Drugie” 2018, nr 3. 
skrawków ksiąg. Za jego pomocą bohaterka próbuje w sposób retroaktywny poradzić sobie z niepokojącym widokiem - takim, od którego nie mogła odwrócić wzroku. Specjalne znaczenie ma tu oczywiście perspektywa dziecka, skazana na brak dostępu do pełnej wiedzy („,nic mi nie opowiadano, dzieci nie miały nic wiedzieć") i zarządzana przez dorosłego (polecenie matki, aby nie patrzyła w stronę Żydów). Na marginesie warto dodać, że z podobnej konceptualizacji dziecięcego spojrzenia na Zagładę korzysta w swojej twórczości Tadeusz Nowak ${ }^{34}$.

W recenzjach Matej Zagtady przewija się pytanie o uniwersalizację Zagłady i zrównanie jej z innymi ludobójstwami czy zjawiskami masowych mordów ${ }^{35}$. Janko w istocie łączy ze sobą i dość dowolnie zestawia informacje na temat różnych masakr, na przykład w Afryce czy Japonii, przywołuje także wątek przemysłowego zabijania zwierząt. Jej książka tworzy tym samym katalog zła i przemocy, ujmujący historię ludzkości przez pryzmat krzywd i cierpień. W ten globalny kontekst Janko wpisuje opowieść o pacyfikacji Soch, rekonstruowaną w rozmowach z matką i jej rodzeństwem, opartą na dodatkowych źródłach i wspomnieniach. Indywidualizację wojennego doświadczenia dopełnia postscriptum zatytułowane Porzadkowanie masakry, będące spisem ofiar pacyfikacji - ludzi i miejsca. W powstałym na podstawie książki filmie ${ }^{36}$ powraca natomiast motyw przeglądania fotografii, tworzenia swego rodzaju albumu, w którym Janko gromadzi zdjęcia z różnych wydarzeń - tym samym fotografie rodzinne zamordowanych dziadków sąsiadują ze zdjęciami z Zagłady (ikoniczne zdjęcie kobiety z dzieckiem na rękach, do której strzela Niemiec, pełni z perspektywy Janko funkcję zastępczego przedstawienia śmierci jej babki). Podjęty przez autorkę wysiłek katalogowania, zestawiania i porządkowania nie jest tylko sposobem na radzenie sobie z rodzinną traumą. Motywuje go także spostrzeżenie, że okupacyjna historia wsi i pamięć o chłopskich ofiarach nie zostały dostatecznie rozpoznane, zbadane czy upamiętnione.

W czym leży przyczyna dyskursywnej nieobecności okupacyjnej historii wsi? Problem ten ogranicza się w dużej mierze do poziomu reprezentacji - braku języka, który pozwalałby opisać doświadczenie chłopskie, braku ugruntowanych narracji konceptualizujących okupacyjne losy wsi czy wizualnych identyfikacji odsyłających do jej historii wojennej. W książce Klub Auschwitz i inne kluby jeden z rozmówców Agnieszki Daukszy, Stefan Lipniak, były więzień obozu koncentracyjnego, stwierdził w nieco innym kontekście:

${ }^{34}$ Zob. K. Koprowska, Postronni? Zagtada w relacjach chtopskich świadków, Kraków 2018.

${ }_{35}$ Zob. L. Nijakowski, Rodzinna apokalipsa, https://kulturaliberalna.pl/2015/03/03/rodzinna-apokalipsa-recenzja-ksiazki-mala-zaglada-anny-janko/, dostęp: 18.10.2020; M. Tomczok, „Ptacz genów”, dz. cyt., s. 326.

36 Zob. Mata Zagtada, reż. N. Koryncka-Gruz, 2018, https://vod.tvp.pl/video/mala-zaglada,mala-zaglada,42034289, dostęp: 23.10.2020. 
Zazdroszczę Żydom Holokaustu. (...) Zazdroszczę im tego terminu Holokaust. Mocny jest. (...) Od razu wiadomo, o co chodzi. A my nie potrafiliśmy nazwać tego, co nas spotkało. „Wojna”, „obozy”, „niewola”? Tyle lat minęło, a my nie mamy nazwy ${ }^{37}$.

Nowa literatura o wsi mierzy się z reprezentacyjną pustką i „doświadczeniem bez nazwy”, co wymaga od niej pracy odpominania doświadczenia wsi i zaproponowania innego języka do jego opisu.

Odpowiadając na ten problem, Karpowicz utrzymuje swoją narrację na granicy baśniowości i realnego, wyrażalnego i niewyrażalnego. W Matej Zagtadzie Janko sięga po retorykę Zagłady i przechwytuje jej charakterystyczne motywy: wykorzystuje dyskurs traumy i jej międzypokoleniowego transferu ${ }^{38}$ (autorka ewidentnie sytuuje się - na wzór piśmiennictwa Zagłady - w roli przedstawicielki drugiego pokolenia); typowe doświadczenia dla „pokolenia postpamięci”; na równi stawia zagładę Żydów i Słowian, mówi o mieniu pożydowskim i popolskim. Czy chodzi więc o zrównanie polskiego i żydowskiego doświadczenia? Ciekawie w tym kontekście wypada obraz ognia i palenia, wspólny skądinąd dla obu doświadczeń - żydowskiego i chłopskiego - oraz obu narracji wiktymizacyjnych. Spalenie wsi Janko próbuje uczynić podstawą - a zatem poszukiwanym identyfikacyjnym elementem - historii chłopskiej martyrologii; próba monopolizacji tego motywu doświadczenia wojny na wsi powoduje jednak wyłączenie z opowieści Jedwabnego. Marta Tomczok diagnozuje, że jedynym obszarem, na którym skonfliktowane pamięci żydowska i polska moga się ze sobą spotkać, jest właśnie retoryka Zagłady ${ }^{39}$. Wydaje się, że w powieści Janko chodzi przede wszystkim o etyczny gest oddania sprawiedliwości chłopskim ofiarom i jednocześnie nobilitowanie okupacyjnego doświadczenia wsi. Tworzenie narracji „małej zagłady” w kontrze do „Wielkiej Zagłady” nie daje szansy na wyjście poza klincz resentymentu i rywalizacji cierpień. Zarówno

${ }^{37}$ We wspomnianej książce autorka diagnozowała polski problem pamięciowo-tożsamościowy, określony przez nią jako „doświadczenie bez nazwy”, czyli „niemożność nazwania, a co za tym idzie, doświadczenia tego, co przydarzyło się znaczącej grupie Polaków podczas okupacji. (...) kwestia dotyczy nie tylko faktycznych byłych więźniów i ich najbliższych włącznie z dziećmi i wnukami - zgodnie z logiką postpamięciowej, transmisyjnej i narracyjnej wymiany - ale także tych, którzy przez kilka lat żyli w obawie przed deportacją do obozu, oraz tych, którzy byli świadkami wywożenia innych, również Żydów”. Odnoszę wrażenie, że podobny problem dotyczy również okupacyjnej historii wsi. Zob. A. Dauksza, Doświadczenie bez nazwy. „Oświęcim” Auschwitz, „Teksty Drugie” 2016, nr 6, s. 234; taż, Klub Auschwitz i inne kluby. Rwane opowieści przeżywców, Gdańsk 2016, s. 17.

38 Anna Artwińska analizuje powieść Janko w kontekście epigenetyki i pokazuje, jak koncepcja transgeneracyjnej pamięci genów zostaje przez autorkę wykorzystana jako argument przemawiający za doznaną traumą. Zob. A. Artwińska, Transfer międzypokoleniowy, epigenetyka $i$ „więzy krwi”. O „Matej Zagtadzie” Anny Janko i „Granicy zapomnienia” Siergieja Lebiediewa, „Teksty Drugie” 2016, nr 1, s. 19-22.

39 M. Tomczok, „Ptacz genów”, dz. cyt., s. 327. 
Sońka Karpowicza, jak i Mata Zagtada Janko sięgają w dużej mierze po znane i sprawdzone poetyki, pozwalają tym samym zidentyfikować główne problemy, konieczności i zagrożenia, jakie rysują się w dyskursie drugiej wojny oraz literaturze z nim powiązanej. To dobry początek, by wykonać kolejny krok.

\section{Bibliografia}

Artwińska A., Transfer międzypokoleniowy, epigenetyka i „więzy krwi”. O „Matej Zagtadzie” Anny Janko i „Granicy zapomnienia” Siergieja Lebiediewa, „Teksty Drugie" 2016, nr 1.

Buryła S., Literatury wojny i okupacji. Koncepcja stownika, „Teksty Drugie” 2020, nr 3.

Czapliński P., Śmierć, śmierć, inne życie. Wieś w literaturze polskiej przetomu XX i XXI wieku, „Teksty Drugie” 2017, nr 6.

Dalej jest noc. Losy Żydów w wybranych powiatach okupowanej Polski, red. B. Engelking, J. Grabowski, t. 1 i 2, Warszawa 2018.

Dauksza A., Doświadczenie bez nazwy. „Oświęcim” Auschwitz, „Teksty Drugie” 2016, nr 6.

Dauksza A., Klub Auschwitz i inne kluby. Rwane opowieści przeżywców, Gdańsk 2016.

Dauksza A., Ludzie nieznaczni doświadczaja przemocy II wojny. O potrzebie badania świadectw bezsilności, „Teksty Drugie” 2020, nr 3.

Dobrosielski P., Spory o Grossa. Polskie problemy z pamięcia o Żydach, Warszawa 2017.

Dobrosielski P., Stodota [w:] Ślady Holocaustu w imaginarium kultury polskiej, red. I. Kurz, J. Kowalska-Leder, M. Szpakowska, P. Dobrosielski, Warszawa 2017.

Engelking B., Jest taki piękny stoneczny dzień... Losy Żydów szukających ratunku na wsi polskiej 1942-1945, Warszawa 2011.

Grabowski J., Judenjagd. Polowanie na Żydów 1942-1945. Studium dziejów pewnego powiatu, Warszawa 2011.

Gross J.T., Sasiedzi, Sejny 2000.

Janko A., Mata Zagtada, Kraków 2015.

Jarosz D., Miernik G., „Zhańbiona” wieś Okót. Opowieści o buncie, Warszawa-Kielce 2016.

Jarzyna A., Imaginauci. Pismo wyobraźni w poezji Bolestawa Leśmiana, Józefa Czechowicza, Krzysztofa Kamila Baczyńskiego, Tadeusza Nowaka, Łódź-Kraków 2017.

Karpowicz I., Sońka, Kraków 2014.

Koprowska K., Klucz do domu, którego nie ma. „Czarny potok” Leopolda Buczkowskiego jako studium oikocydu, „Teksty Drugie” 2020, nr 3.

Koprowska K., Konflikt miejsca urodzenia w „Sońce” Ignacego Karpowicza, „Tematy i Konteksty" 2017, nr 7. 
Koprowska K., Postronni? Zagtada w relacjach chtopskich świadków, Kraków 2018. Koziołek R., Dobrze się myśli literatura, Wołowiec 2016.

Krupa B., II wojna światowa w prozie Wiestawa Myśliwskiego [w:] Myśl Myśliwskiego (studia i eseje), red. J. Olejniczak, M. Boniecka, P. Zając, Katowice 2018.

Krupa B., Historia krytyczna i jej "gabinet cieni". Historiografia polska wobec Zagtady 2003-2013, „Zagłada Żydów” 2014, nr 10, t. 2 (Materiały).

Leder A., Przénniona rewolucja. Ćwiczenie z logiki historycznej, Warszawa 2014.

Leszczyński A., Ludowa historia Polski, Warszawa 2020.

Mata Zagtada, reż. N. Koryncka-Gruz, 2018, https://vod.tvp.pl/video/mala-zaglada,mala-zaglada,42034289, dostęp: 23.10.2020.

Małczyński J., Krajobrazy Zagtady w sztuce wspótczesnej [w:] tegoż, Krajobrazy Zagtady. Perspektywa historii środowiskowej, Warszawa 2018.

Markiel T., Skibińska A., "Jakie to ma znaczenie, czy zrobili to z chciwości?” Zagtada domu Trynczerów, Warszawa 2011.

Nijakowski L., Rodzinna apokalipsa, https://kulturaliberalna.pl/2015/03/03/rodzinna-apokalipsa-recenzja-ksiazki-mala-zaglada-anny-janko/, dostęp: 18.10.2020.

Ostrowska J., Przemilczane. Seksualna praca przymusowa w czasie II wojny światowej, Warszawa 2018.

Płaza M., Skoruń, Warszawa 2015.

Prowincja noc. Życie i zagłada Żydów w dystrykcie warszawskim, red. B. Engelking, J. Leociak, D. Libionka, Warszawa 2007.

Rauszer M., Bękarty pańszczyzny. Historia buntów chtopskich, Warszawa 2020.

Rothberg M., Pamięć wielokierunkowa. Pamiętanie Zagtady w epoce dekolonizacji, Warszawa 2015.

Sendyka R., Od obserwatorów do gapiów. Kategoria bystanders $i$ analiza wizualna, „Teksty Drugie” 2018, nr 3.

Sienkiewicz B., Ślady wojny i Holokaustu w sieci spotecznych dyskursów. O „Ościach” i „Sońce” Ignacego Karpowicza [w:] Ślady II wojny światowej i Zagtady w najnowszej literaturze polskiej, red. B. Sienkiewicz, S. Karolak, Poznań 2016.

Skibińska A., Petelewicz J., Udziat Polaków w zbrodniach na Żydach na prowincji regionu świętokrzyskiego, „Zagłada Żydów” 2005, nr 1.

Ślady Holokaustu w imaginarium kultury polskiej, red. P. Dobrosielski, J. Kowalska-Leder, I. Kurz, M. Szpakowska, Warszawa 2017.

Świadek. Jak się staje, czym jest?, red. A. Dauksza, K. Koprowska, Warszawa 2019.

Tokarska-Bakir J., Btąd pomiaru. O artykule Barbary Engelking „Powiat bielski”, „Teksty Drugie” 2018, nr 5.

Tokarska-Bakir J., Rzeczy mgliste. Eseje i studia, Sejny 2004.

Tomczok M., Czyja dzisiaj jest Zagtada? Retoryka - ideologia - popkultura, Warszawa 2017.

Tomczok M., „Płacz genów”, „Narracje o Zagładzie” 2015, nr 1.

Zarys krajobrazu. Wieś polska wobec Zagtady Żydów 1942-1945, red. B. Engelking, J. Grabowski, Warszawa 2011. 
Zbrodnie hitlerowskie na wsi polskiej w latach 1939-1945. Wspomnienia, pamiętniki i relacje, red. S. Durlej, J. Gmitruk, Kielce-Warszawa 2008.

Żbikowski A., Krótka historia stosunków polsko-żydowskich we wsi Grądy Woniecko w roku 1942 [w:] Świat NIEpożegnany. Żydzi na dawnych ziemiach wschodnich Rzeczypospolitej $w$ XVIII-XX wieku, red. K. Jasiewicz, Warszawa-Londyn 2004. 